\title{
Tracer concentration profiles measured in central London as part of the REPARTEE campaign
}

\author{
D. Martin ${ }^{1,}{ }^{*}$, K. F. Petersson ${ }^{1}$, I. R. White ${ }^{1}$, S. J. Henshaw ${ }^{1}$, G. Nickless ${ }^{1}$, A. Lovelock ${ }^{1}$, J. F. Barlow ${ }^{2}$, T. Dunbar ${ }^{2}$, \\ C. R. Wood ${ }^{2}$, and D. E. Shallcross ${ }^{1}$ \\ ${ }^{1}$ School of Chemistry, University of Bristol, Cantock's Close, Bristol, BS8 1TS, UK \\ ${ }^{2}$ Department of Meteorology, University of Reading, Reading, RG6 6BB, UK \\ *now at: Centre for Climate and Air Pollution Studies, National University of Ireland Galway, Galway, Ireland
}

Received: 30 September 2009 - Published in Atmos. Chem. Phys. Discuss.: 25 November 2009

Revised: 30 November 2010 - Accepted: 7 December 2010 - Published: 12 January 2011

\begin{abstract}
There have been relatively few tracer experiments carried out that have looked at vertical plume spread in urban areas. In this paper we present results from two tracer (cyclic perfluorocarbon) experiments carried out in 2006 and 2007 in central London centred on the BT Tower as part of the REPARTEE (Regent's Park and Tower Environmental Experiment) campaign. The height of the tower gives a unique opportunity to study vertical dispersion profiles and transport times in central London. Vertical gradients are contrasted with the relevant Pasquill stability classes. Estimation of lateral advection and vertical mixing times are made and compared with previous measurements. Data are then compared with a simple operational dispersion model and contrasted with data taken in central London as part of the DAPPLE campaign. This correlates dosage with non-dimensionalised distance from source. Such analyses illustrate the feasibility of the use of these empirical correlations over these prescribed distances in central London.
\end{abstract}

\section{Introduction}

There have many been many atmospheric tracer experiments carried out in urban areas (Hanna et al., 2003; Venkatram et al., 2004) which have focused on the horizontal spread and/or the along-wind spread of the plume. There have been relatively few investigations into the vertical plume spread, in the main because of the feasibility of making measurements away from the surface. The tracer experiments under-

Correspondence to: D. Martin]

(d.martin@bris.ac.uk) taken here complement the experiments undertaken during the CityFlux campaign in central Manchester, United Kingdom (UK), which also focused on vertical tracer gradients in urban areas (Petersson et al., 2010).

In urban areas the URGENT (URban Regeneration and the $E N$ vironmenT) campaign undertaken in Birmingham, UK, 1999-2000, was probably the first tracer experiment conducted to publish results concerning vertical concentration profiles in an urban area. Here a uniform vertical profile was found in a $20 \mathrm{~m}$ deep street canyon around one kilometre away from the source (Cooke et al., 2000). The results were compared with the ADMS3 model developed by CERC and there was good agreement (Britter, 2002). Similar results were found during the BUBBLE (Basel UrBan BoundaryLayer Experiment) tracer experiments in Basel, Switzerland. Here a uniform vertical profile was found in a $17 \mathrm{~m}$ deep street canyon, $700 \mathrm{~m}$ away from the source. In these experiments, three receptors were utilised: one at ground level, one at $10 \mathrm{~m}$ and one at a roof level of $17 \mathrm{~m}$ (Rotach et al., 2004).

The most extensive set of tracer experiments regarding vertical dispersion was undertaken in Oklahoma City during the Joint Urban 2003 campaign. An instrumented crane system was developed and receptors were placed approximately every $5 \mathrm{~m}$ from about $10 \mathrm{~m}$ to up to $75 \mathrm{~m}$ ( 7 receptors in total). The sampling crane was placed approximately $1000 \mathrm{~m}$ away from the $\mathrm{SF}_{6}$ release site (Flaherty et al., 2007). A total of 32 releases were made both during daytime and night-time. For the daytime experiments conducted in July, the results indicate that the plume was relatively well mixed where the lowest concentration measured in the vertical profile was typically within $50 \%$ of the maximum concentration. However, maximum concentration was measured more often in the lower half of the profile. The day-time and night-time results

Published by Copernicus Publications on behalf of the European Geosciences Union. 
revealed only a slight difference, though a less uniform profile was seen during night-time indicating that convective mixing is important for dispersion (Flaherty et al., 2007). During the Joint Urban 2003 campaign, one experiment was also carried out where the source-receptor distance was only $500 \mathrm{~m}$. Here, a distinct vertical concentration profile was revealed where the $75-\mathrm{m}$ receptor measured one quarter to one half of the maximum concentration that tended to be nearer the ground than when source receptor distance was 1000 metres (Flaherty et al., 2007). This highlights the dependence of vertical concentration profiles on distances downstream. Five experiments investigating vertical dispersion were also undertaken in the early-to-mid twentieth century. Here, more disparate tracers such as smoke at Porton Down, UK, 19231924, (Pasquill, 1974), sulphur dioxide during Prairie Grass (Nieuwstadt and van Ulden, 1978) and zinc cadmium sulphide during Green Glow (Barad and Fuquay, 1961) were used. The data-set most extensively used for evaluating vertical concentration profiles has been the Prairie Grass dataset. One complication with this dataset though is the use of sulphur dioxide as a tracer which is known to undergo dry and wet deposition. The deposition needs to be taken into account when analysing these data (Britter and Hanna, 2003). As well as field studies there have been laboratory and wind tunnel studies which have attempted to characterise vertical dispersion in the turbulent boundary layer (Robins et al., 2001; Briggs et al., 2001; Britter et al., 2003).

The present paper presents data from tracer experiments completed during two campaigns in 2006 and 2007 of the REPARTEE (the REgent's PARk and Tower Environmental Experiment) project in central London, UK. The sourcereceptor distances ranged between 500 and $1000 \mathrm{~m}$, with the highest receptor at $190 \mathrm{~m}$, which allowed better determination of the dependence of the concentration profile on height. Accompanying Doppler lidar measurements elucidated the turbulent structure of the boundary layer.

\section{Experimental}

\subsection{Site description (building morphology)}

The BT Tower ( $51.3117 \mathrm{~N}, 0.1389 \mathrm{~W})$ is located in Fitzrovia in central London (see Fig. 1). The main structure is 177$\mathrm{m}$ tall with a further section of lattice tower bringing the height up to $190 \mathrm{~m}$. It has had grade- 2 listed building status since 2003. The experimental area consists of densely packed mixed residential and commercial buildings with 45 storeys. Buildings within $250 \mathrm{~m}$ of the nearby DAPPLE project site (Wood et al., 2009) have a mean height of $21 \mathrm{~m}$ and a maximum height of approximately $50 \mathrm{~m}$. (a)

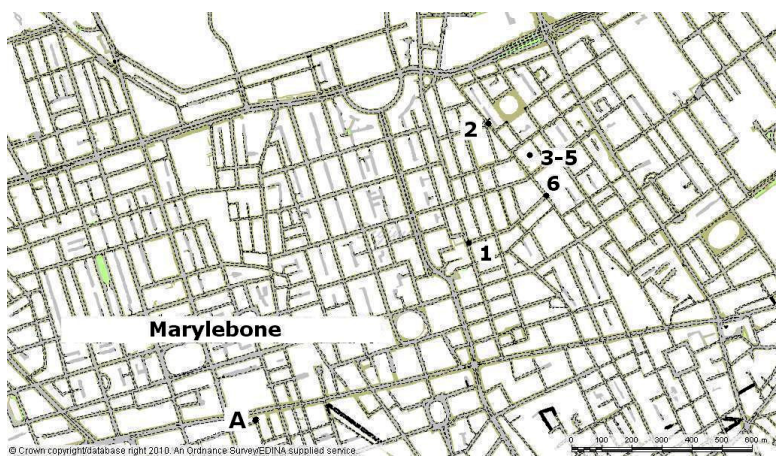

(b)

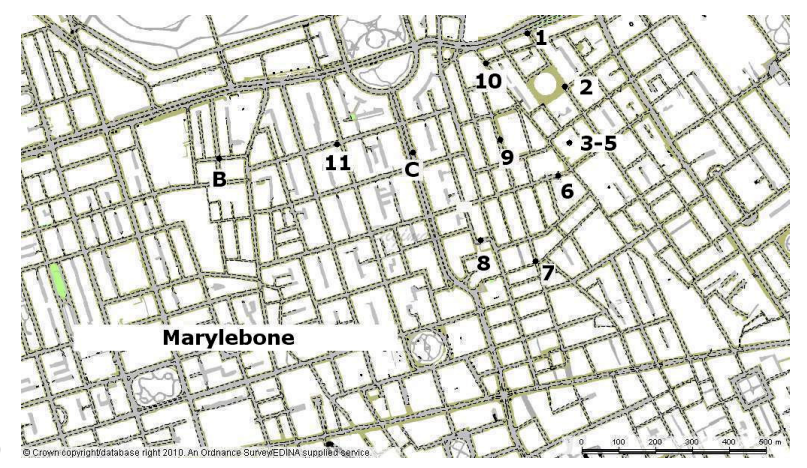

Fig. 1. (a) Experimental setup for the REPARTEE I. Source locations: A Receptor locations: 1 to 10. Note: receptors 3 to 5 located at heights $1.5 \mathrm{~m}, 160$ and $190 \mathrm{~m}$ on BT Tower. (b) Experimental setup for the REPARTEE II. Source locations: B and C Receptor locations: 1 to 10 . Note: receptors 3 to 5 located at heights $1.5 \mathrm{~m}$, 160 and $190 \mathrm{~m}$ on BT Tower.

\subsection{Tracers (technique, layout, source-receptor distances)}

\subsubsection{Technique}

Tracers used in this experiment are inert, non-toxic and are a specific type of perfluorocarbon called a perfluoroalkylcycloalkane which are based around a saturated carbon ring which is fully fluorinated. Typical atmospheric background concentrations for the most commonly used perfluorocarbons in tracer experiments are in the low ppqv range (Simmonds et al., 2002; Kim et al., 2002; Watson et al., 2007) and the current growth rate is, if any growth rate at all, less than 1 ppqv per year (Watson et al., 2007). These compounds have been used previously in dispersion experiments ranging from long range studies (Draxler et al., 1991; Straume et al., 1998) down to city and neighbourhood scales (Arnold et al., 2004; Martin et al., 2008; Martin et al., 2010a, b; Shallcross et al., 2009; Wood et al., 2009). 
Table 1a. Experimental details for REPARTEE I.

\begin{tabular}{|c|c|c|c|c|c|c|c|}
\hline \multirow[b]{2}{*}{$\begin{array}{l}\text { Receptor and } \\
\text { Release positions }\end{array}$} & \multicolumn{7}{|c|}{ REPARTEE I } \\
\hline & $\begin{array}{l}\text { A } \\
\text { (release) }\end{array}$ & 1 & 2 & 3 & 4 & 5 & 6 \\
\hline Position or Intersection of & $\begin{array}{l}\text { North } \\
\text { Row and } \\
\text { Balder- } \\
\text { ton Street }\end{array}$ & $\begin{array}{l}\text { Great Port- } \\
\text { land St \& } \\
\text { Langham St }\end{array}$ & $\begin{array}{l}\text { Cleveland } \\
\text { St \& } \\
\text { Clipstone } \\
\text { Mews }\end{array}$ & $\begin{array}{l}\text { BT } \\
\text { Tower, } \\
\text { ground } \\
\text { level }\end{array}$ & $\begin{array}{l}\text { BT } \\
\text { Tower, } \\
160 \mathrm{~m}\end{array}$ & $\begin{array}{l}\text { BT } \\
\text { Tower, } \\
190 \mathrm{~m}\end{array}$ & $\begin{array}{l}\text { Cleveland } \\
\text { St \& Fo- } \\
\text { ley St }\end{array}$ \\
\hline GPS coordinates & $\begin{array}{l}51.5137 \\
0.152467\end{array}$ & $\begin{array}{l}51.5189 \mathrm{~N} \\
0.1422 \mathrm{~W}\end{array}$ & $\begin{array}{l}51.5225 \mathrm{~N} \\
0.1411 \mathrm{~W}\end{array}$ & $\begin{array}{l}51.5214 \mathrm{~N} \\
0.1389 \mathrm{~W}\end{array}$ & $\begin{array}{l}51.5214 \mathrm{~N} \\
0.1389 \mathrm{~W}\end{array}$ & $\begin{array}{l}51.5214 \mathrm{~N} \\
0.1389 \mathrm{~W}\end{array}$ & $\begin{array}{l}51.5202 \mathrm{~N} \\
0.1384 \mathrm{~W}\end{array}$ \\
\hline $\begin{array}{l}\text { Approximate distance from release } \\
\text { position }(\mathrm{m})\end{array}$ & NA & 920 & 1240 & 1270 & 1280 & 1280 & 1230 \\
\hline $\begin{array}{l}\text { Angle from release postion } \\
\left({ }^{\circ} \text { from } \mathrm{N}\right)\end{array}$ & NA & 229 & 218 & 226 & 226 & 226 & 231 \\
\hline Distance above ground (m) & 0.36 & 1.5 & 1.5 & 1.5 & 150 & 190 & 1.5 \\
\hline
\end{tabular}

\subsubsection{Release}

Cyclic perfluoroalkanes were obtained as pure liquids (F2 chemicals Ltd., Lancashire, UK) and gravimetric dilutions of Perfluoromethylcyclopentane (PMCP) and Perfluoromethylcyclohexane (PMCH) were prepared (Linde Gases Ltd., UK). Release gases were prepared at appropriate gaseous concentrations (PMCP 4\%, $\mathrm{PMCH} 1.5 \%$, and $\mathrm{PDMCH}$ $0.25 \%$ ) in air with certification accuracy of $\pm 2 \%$. The release apparatus consisted of stainless steel 15 litre silica lined canister (Restek Ltd., Bellefonte, PA, USA). A specialist software programme, READ30, which is supplied by the manufacturer, monitors the output from the pressure transmitter. Temperature dependencies and non-linearity of the sensors are mathematically compensated for after the release (given the known air temperature). The gas flow rate was controlled by the use of a Flostat Flow Controller (Type MNBS12) (Roxspur Measurement and Control Ltd., Hampshire, UK).

\subsubsection{Sampling}

Samples were taken at each receptor position using an airsampling pump (SKC Ltd., Dorset, UK) sampling at a flow rate of about 0.9 litres per minute and taking air from approximately $1.5 \mathrm{~m}$ above ground level. Samples were collected in 10 litre Tedlar bags (SKC Ltd., Dorset, UK). The release/sampling start time was synchronised for all release and receptor sites by the use of radio-controlled clocks. Physical isolation of the release and sampling teams was ensured at all times (before, during and after the experiment), in order to avoid contamination of the collected air samples.

\subsubsection{Analysis}

The analytical instrumentation consisted of gas chromatograph (Model 6890, Hewlett Packard Ltd., USA) attached to a mass selective detector (Model 5973, Hewlett Packard Ltd., USA). For determining cyclic perfluorocarbon concentrations, the mass spectrometer was operated in negative ion chemical ionisation (NICI) as well as selected ionmonitoring (SIM) mode. The technique is highly selective and sensitive, due to very efficient formation of stable molecular anions. For pre-concentration of the samples, an adsorption desorption system (ADS) was used. Varying volumes of calibration standard were trapped onto a cryogenicallycooled micro-trap filled with a carbon-based adsorbent. The trap was maintained at a temperature of $-50{ }^{\circ} \mathrm{C} \pm 3{ }^{\circ} \mathrm{C}$ during sampling. The adsorbent used was $10 \mathrm{mg}$ Carboxen 569, 40-50 Mesh (Supelco, Bellefonte, USA). It is possible to trap several litres of air onto the adsorbent filled micro-trap without exceeding the theoretical breakthrough volumes (BTV). The trap was cleaned under an auxiliary flow of helium at a temperature of $255^{\circ} \mathrm{C}$ and this process was replicated four times. The trap was quantitatively desorbed at $255^{\circ} \mathrm{C}$. Negligible band broadening occurred due to the small internal diameter of the micro-trap along with the rapid thermal desorption (3-4 s duration). Samples were calibrated using a dilution of a gravimetrically prepared standard purchased from Linde Gases Ltd., UK. During both sets of experiments, receptors were positioned so as to ensure that the BT Tower as close to the estimated plume centre-line as possible. This was done by assessing real time data from a Väisälä WXT510 weather station positioned on top of the BT Tower. 
Table 1b. Experimental details for REPARTEE II.

\begin{tabular}{|c|c|c|c|c|c|c|c|}
\hline \multicolumn{8}{|c|}{ REPARTEE II } \\
\hline $\begin{array}{l}\text { Receptor and Release } \\
\text { positions }\end{array}$ & $\begin{array}{l}\text { B } \\
\text { (release) }\end{array}$ & $\begin{array}{l}\mathrm{C} \\
\text { (release) }\end{array}$ & 1 & 2 & 3 & 4 & 5 \\
\hline $\begin{array}{l}\text { Position or } \\
\text { Intersection of }\end{array}$ & $\begin{array}{l}\text { Notingham } \\
\text { Stret and } \\
\text { Notingham } \\
\text { Place }\end{array}$ & $\begin{array}{l}\text { Portland } \\
\text { Place }\end{array}$ & $\begin{array}{l}\text { East Side } \\
\text { of Fitzroy } \\
\text { Street }\end{array}$ & $\begin{array}{l}\text { Fitzroy } \\
\text { Street and } \\
\text { Grafton way }\end{array}$ & $\begin{array}{l}\text { BT Tower, } \\
\text { ground level }\end{array}$ & $\begin{array}{l}\text { BT Tower, } \\
160 \mathrm{~m}\end{array}$ & $\begin{array}{l}\text { BT Tower, } \\
190 \mathrm{~m}\end{array}$ \\
\hline GPS coordinates & $\begin{array}{l}51.5214 \mathrm{~N} \\
0.1531 \mathrm{~W}\end{array}$ & $\begin{array}{l}51.5216 \mathrm{~N} \\
0.1456 \mathrm{~W}\end{array}$ & $\begin{array}{l}51.5243 \mathrm{~N} \\
0.1407 \mathrm{~W}\end{array}$ & $\begin{array}{l}51.5229 \mathrm{~N} \\
0.1392 \mathrm{~W}\end{array}$ & $\begin{array}{l}51.5215 \mathrm{~N} \\
0.1389 \mathrm{~W}\end{array}$ & $\begin{array}{l}51.5215 \mathrm{~N} \\
0.1389 \mathrm{~W}\end{array}$ & $\begin{array}{l}51.5215 \mathrm{~N} \\
0.1389 \mathrm{~W}\end{array}$ \\
\hline $\begin{array}{l}\text { Approximate distance } \\
\text { from release positions (m) }\end{array}$ & NA & NA & $\begin{array}{l}910(\mathrm{~B}) \\
460(\mathrm{C})\end{array}$ & $\begin{array}{l}980(\mathrm{~B}) \\
470(\mathrm{C})\end{array}$ & $\begin{array}{l}980(\mathrm{~B}) \\
460(\mathrm{C})\end{array}$ & $\begin{array}{l}980(B) \\
460(\mathrm{C})\end{array}$ & $\begin{array}{l}980(\mathrm{~B}) \\
460(\mathrm{C})\end{array}$ \\
\hline $\begin{array}{l}\text { Angle from release } \\
\text { postion }\left({ }^{\circ} \text { from } N\right)\end{array}$ & NA & NA & $\begin{array}{l}248(B) \\
226(C)\end{array}$ & $\begin{array}{l}258(\mathrm{~B}) \\
249(\mathrm{C})\end{array}$ & $\begin{array}{l}267(\mathrm{~B}) \\
270(\mathrm{C})\end{array}$ & $\begin{array}{l}267(\mathrm{~B}) \\
270(\mathrm{C})\end{array}$ & $\begin{array}{l}267(\mathrm{~B}) \\
270(\mathrm{C})\end{array}$ \\
\hline $\begin{array}{l}\text { Distance above } \\
\text { ground }(\mathrm{m})\end{array}$ & $0.39 \mathrm{~m}$ & $0.39 \mathrm{~m}$ & 1.5 & 1.5 & 1.5 & 150 & 190 \\
\hline Receptor positions & 6 & 7 & 8 & 9 & 10 & 11 & \\
\hline $\begin{array}{l}\text { Position or } \\
\text { Intersection of }\end{array}$ & $\begin{array}{l}\text { Ogle Street } \\
\text { North }\end{array}$ & $\begin{array}{l}\text { Great Titch- } \\
\text { field Street }\end{array}$ & $\begin{array}{l}\text { Gilder } \\
\text { Street }\end{array}$ & $\begin{array}{l}\text { Great Titch- } \\
\text { field Street }\end{array}$ & $\begin{array}{l}\text { Cleveland } \\
\text { Street and } \\
\text { Warren St. }\end{array}$ & $\begin{array}{l}\text { Harley and } \\
\text { Devonshire } \\
\text { Street }\end{array}$ & \\
\hline GPS coordinates & $\begin{array}{l}51.5206 \mathrm{~N} \\
0.1400 \mathrm{~W}\end{array}$ & $\begin{array}{l}51.5186 \mathrm{~N} \\
0.1406 \mathrm{~W}\end{array}$ & $\begin{array}{l}51.5191 \mathrm{~N} \\
0.1427 \mathrm{~W}\end{array}$ & $\begin{array}{l}51.5216 \mathrm{~N} \\
0.1420 \mathrm{~W}\end{array}$ & $\begin{array}{l}51.5235 \mathrm{~N} \\
0.1424 \mathrm{~W}\end{array}$ & $\begin{array}{l}51.5217 \mathrm{~N} \\
0.1482 \mathrm{~W}\end{array}$ & \\
\hline $\begin{array}{l}\text { Approximate distance } \\
\text { from release positions (m) }\end{array}$ & $\begin{array}{l}910(\mathrm{~B}) \\
400(\mathrm{C})\end{array}$ & $\begin{array}{l}930(\mathrm{~B}) \\
480(\mathrm{C})\end{array}$ & $\begin{array}{l}770(\mathrm{~B}) \\
340(\mathrm{C})\end{array}$ & $\begin{array}{l}770(\mathrm{~B}) \\
260(\mathrm{C})\end{array}$ & $\begin{array}{l}790(\mathrm{~B}) \\
330(\mathrm{C})\end{array}$ & $\begin{array}{l}350(\mathrm{~B}) \\
170(\mathrm{C})\end{array}$ & \\
\hline $\begin{array}{l}\text { Angle from release } \\
\text { postion }\left({ }^{\circ} \text { from } N\right)\end{array}$ & $\begin{array}{l}273(\mathrm{~B}) \\
282(\mathrm{C})\end{array}$ & $\begin{array}{l}288(\mathrm{~B}) \\
311(\mathrm{C})\end{array}$ & $\begin{array}{l}287(\mathrm{~B}) \\
320(\mathrm{C})\end{array}$ & $\begin{array}{l}265 \text { (B) } 263 \\
\text { (C) }\end{array}$ & $\begin{array}{l}250 \text { (B) } 224 \\
\text { (C) }\end{array}$ & $\begin{array}{l}263(\mathrm{~B}) \\
94(\mathrm{C})\end{array}$ & \\
\hline $\begin{array}{l}\text { Distance above } \\
\text { ground }(\mathrm{m})\end{array}$ & 1.5 & 1.5 & 1.5 & 1.5 & 1.5 & 1.5 & \\
\hline
\end{tabular}

\subsection{Experimental layout and source-receptor distances}

\subsubsection{REPARTEE I: 26 October 2006}

An arc of four receptors with a vertical array of three centred on the BT Tower site (ground level, $160.3 \mathrm{~m}$ agl and $190 \mathrm{~m}$ a.g.1.) was positioned as outlined in Fig. 1a. The layout of these, along with the relevant source-receptor distances, is shown in Table 1a. The release of PMCP was made at the intersection of North Row and Balderton Street. The buildings surrounding the release positions are mostly $4-5$ storeys high. The release position was about $1300 \mathrm{~m}$ upwind of BT Tower. North Row is a one-way street: traffic flows towards the east along North Row. No access from Balderton Street onto Oxford Street is possible. Almost no traffic was observed on North Row or Balderton Street during the entire release period. Tracer was released for 59 min between 13:50 and 14:49 UTC at a height of $0.36 \mathrm{~m}$ at an average release rate of $3.348 \pm 0.076 \times 10^{-6} \mathrm{~kg} \mathrm{~s}^{-1}$. Six samples were taken at each sampling position according to the following scheme, allowing for one minute in between each sample in order to have time for personnel to change bags to the sampling pump [1: 13:50-13:59, 2: 14:00-14:09, 3: 14:10-14:19, 4: 14:2014:29, 5: 14:30-14:39, 6: 14:40-14:49]. Table 1 gives the distances from source to the receptor along with the bearing from north of the source with respect to the receptor.

\subsubsection{REPARTEE II: 7 November 2007}

Six dosage experiments (35 min sampling compared with 15 min releases) were undertaken from two release positions with samples taken at 11 receptor sites). Each of the six releases (Start times: 13:00:00, 13:45:00, 14:30:00, 15:15:00, 16:00:00 and 16:45:00 UTC) was accompanied by concurrently starting sampling times. The layout of these is shown in Fig. $1 \mathrm{~b}$ whilst release positions, sampling positions and source receptor distances are shown in Table 1b. Receptors 
3-5 refer to ground level, $160 \mathrm{~m}$ and $190 \mathrm{~m}$ at the tower respectively.

\subsection{Meteorological measurements}

Meteorological measurements were made at the top of the lattice tower on top of the BT Tower using a Gill ultrasonic anemometer (R3-100 with symmetric head) sampling at $20 \mathrm{~Hz}$. An automated weather station (Väisälä WXT510) was also attached to the lattice tower. The anemometer was clamped to an open lattice scaffolding tower of $12 \mathrm{~m}$ height, situated on top of the main building structure and resulting in a measurement height of $190 \mathrm{~m}$. A secondary meteorological reference was mounted on the roof of the Westminster City Council (WCC) Library $\left(51.5210^{\circ} \mathrm{N}, 0.1605^{\circ} \mathrm{W}\right.$, the roof and anemometer head heights were $15.5 \mathrm{~m}$ and $18.4 \mathrm{~m}$ respectively; see Barlow et al., 2009 and Wood et al., 2010).

Doppler lidar (LIght Detection And Ranging) measurements were taken during the 2007 REPARTEE II campaign (Barlow et al., 2010). The instrument was a Halo Photonics 1.5 micron scanning Doppler lidar sited in the car-park of the University of Westminster on Marylebone Road (the Salford Doppler lidar is part of the National Centre for Atmospheric Science (NCAS) Facility for Ground-based Atmospheric Measurement (FGAM)). The instrument ran continuously from 24 October to 14 November 2007 including the 7 November when REPARTEE II tracer experiments were carried out. Due to the proximity and height of the neighbouring buildings, the lidar was restricted in its view of the sky, and in this paper only the vertical stare measurements are reported i.e. the lidar pointed directly upwards, measuring the vertical velocity component of turbulent mixing and aerosol backscatter to a height resolution of $30 \mathrm{~m}$ at a sampling rate of $0.25 \mathrm{~Hz}$. One of the main advantages of using a high resolution remote sensing instrument such as a lidar was to provide turbulent profiles of the boundary layer alongside the tracer experiments, and to determine boundary layer depth.

\section{Results and discussion}

\subsection{Meteorological results and lidar data}

Shown in Table 3 are the anemometry measurements made during REPARTEE I and II. An extensive study of the relationship between the meteorology of the two reference anemometry sites was undertaken, studying the relationship between wind speeds measured at the BT Tower and the top of WCC as part of the DAPPLE project (Arnold et al., 2004; Barlow et al., 2009; Martin et al., 2010a, b). This showed a high degree of correlation between the measurements with the ratio of the mean values of BT Tower/WCC wind speeds being in the region of 4.1:1 over the whole year (although a slope of 5.7 is obtained when a linear regression is performed through 30-min means). The values of BT Tower/WCC wind speed during the 2007 experiments were slightly higher than the annual average value but well within the range of measurements made and can be judged to be typical conditions. Shown in Fig. 2 are the lidar measurements (Barlow et al., 2010) for the REPARTEE II campaign.

The backscatter and velocity variance data from the lidar were used to ascertain different heights relating to the boundary layer. The boundary-layer top was defined by the largest gradient in the backscatter found going from the top of the profile downwards; while the ground-based aerosollayer depth was defined by the first exceedance of the threshold value of backscatter gradient $\left(-4 \times 10^{-9} \mathrm{~m}^{-2} \mathrm{sr}^{-1}\right)$ looking from the ground upwards. The mixing height was defined as the height up to which a threshold of vertical velocity variance $\sigma_{w}^{2}>0.1 \mathrm{~m}^{2} \mathrm{~s}^{-2}$ was met. The 7 November 2007 (REPARTEE II) was predominantly overcast due to a shallow layer of stratocumulus (shown by enhanced backscatter at approximately $1 \mathrm{~km}$ ) and mean wind speed was above-average compared to the rest of the REPARTEE II campaign $\left(7.4 \mathrm{~m} \mathrm{~s}^{-1}\right)$. Weak daytime convective mixing occurred throughout the whole boundary layer from c. 11:00 until 15:00, and was replaced by a ground-based turbulent layer, driven by wind shear. The large amount of cloud cover might suggest that there is little convection. However, the large values of vertical velocity variance throughout the central depth of the mixed layer, along with the characteristic profile (with a peak in vertical velocity variance near the boundary layer centre), is indicative of convectively-driven turbulence. Given the $z / L$ values, it would seem that the boundary layer was weakly convective. Hence, comparable stability is assumed, classes $\mathrm{C}$ (slight incoming solar radiation, moderate wind speed) and $\mathrm{D}$ (overcast) according to Pasquill's 10 stability classes. The neutral height scale $\left(u_{*} / f\right)$ is of order $1 \mathrm{~km}$, however there is evidence of the boundary-layer being weakly unstable since the sonic anemometer data showed $z / L$ values $<-0.1$.

\subsection{Concentration-time profiles and general comments}

\subsubsection{REPARTEE I}

Figure 3 shows the sequence of averaged 9-min concentrations at six receptor positions for REPARTEE I. Values are plotted in the form of $\mathrm{C} / \mathrm{Q}$ values, where $\mathrm{C}$ is the concentration in $\mathrm{kg} \mathrm{m}^{-3}$ at $20^{\circ} \mathrm{C}$ and $\mathrm{Q}$ is the release rate in $\mathrm{kg} \mathrm{s}^{-1}$. $\mathrm{C} / \mathrm{Q}$ values for REPARTEE I and $\mathrm{D} / \mathrm{Q}$ (where $\mathrm{D}$ is the dosage of gas accumulated over the sampling time, $\mathrm{D}\left(\right.$ in $\left.\mathrm{kg} \mathrm{m}^{-3} \mathrm{~s}\right)$ ) values for REPARTEE II are shown in Table 2.

\subsubsection{REPARTEE II}

$\mathrm{D} / \mathrm{Q}$ (where $\mathrm{D}$ is the dosage of gas accumulated over the sampling time, $\mathrm{D}$ (in $\mathrm{kg} \mathrm{m}^{-3} \mathrm{~s}$ )) values for REPARTEE II are shown in Table 2. Provisional comparison of receptors 8,9 , 10 (Fig. 4) on arc 1 shows that plume was centred on the BT 

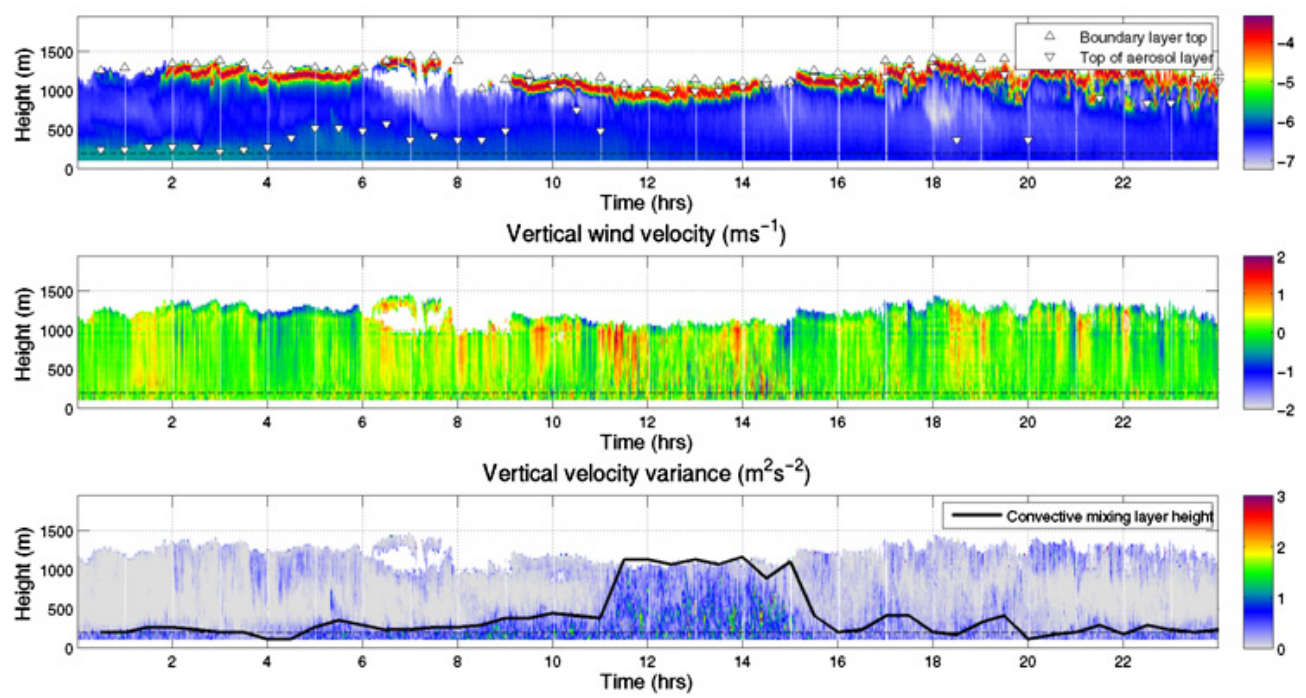

Fig. 2. Lidar measurements during REPARTEE II (all times UTC) showing the boundary layer top, top of the aerosol layer, vertical wind velocity and the convective layer mixing height.
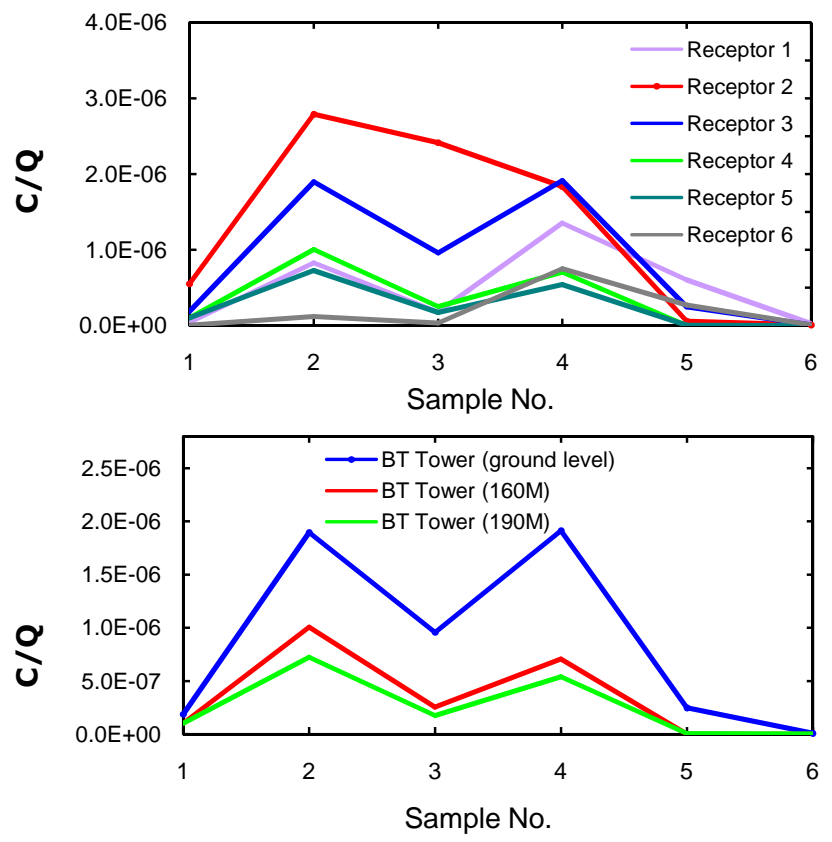

Fig. 3. Time series of concentrations for REPARTEE I. The top panel shows the averaged 9 min values at all off the receptors while the bottom panel shows an expanded representation of the values from the BT Tower.

Tower for experiments 3,4 and 5. The relative concentrations suggest that the plume centreline was south of the BT Tower for experiments 1 and 2, giving highest concentrations at receptor 8 . This pattern is confirmed by receptors $1,2,3$, 6,7 - with higher concentrations at southern-most receptor 7 for earlier experiments, although the pattern is not so clear.

\subsection{Vertical distribution and advection times}

\subsubsection{Vertical gradient}

The dataset most extensively used for evaluating vertical concentration profiles has been the Prairie Grass data set. One complication with these data though is the use of sulphur dioxide (noted previously) and that its deposition needs to be taken into account when analysing these data (Britter and Hanna, 2003). The results from the early-to-mid twentieth century experiments were later analysed in the main by comparing the results with equation 1 , which is a generalisation of the Gaussian plume model. The main aim has been to determine the shape exponents:

$$
\left(\frac{\chi_{Z}}{\chi_{0}}\right)=\exp \left[-b\left(\frac{z}{\bar{z}}\right)^{s}\right],
$$

where $\chi$ is the concentration at an elevated $(z)$ position and at ground level $(0), b$ is constant and $\bar{z}$ is the average plume height. A value of $s=1$ implies an exponential vertical profile and $s=2$ for a Gaussian vertical profile. Numerous windtunnel studies have been made in order to investigate vertical dispersion. A review of previous measurements showed values of $s$ that varied between 1.4 and 2.25 (Britter et al., 2003). One reference to unpublished data (Courtney, 1979 in Britter et al., 2003) showed that $s$ slightly decreased with downwind distance which is in excellent agreement with the results published here.

Hunt and Weber (1979) concluded that s should decrease with increasing source-receptor distance. At shorter sourcereceptor distances, the plume will be dispersed closer to the ground in the surface layer where the value of $\alpha$ (the exponent in the best fit power law describing the relationship 
Table 2. Tracer data at various receptor positions (See Fig. 1 for location) during REPARTEE I and II. (NDFB- Non discernible from background).

\begin{tabular}{lllllll}
\hline \multicolumn{2}{c}{ REPARTEE I Background subtracted concentration/Release rate $\left(10^{8} \mathrm{~s} / \mathrm{m}^{3}\right)$} \\
\hline \multirow{2}{*}{ Sampling interval } & \multicolumn{7}{c}{ Receptor position } \\
\cline { 2 - 7 } & 1 & 2 & 3 & 4 & 5 & 6 \\
$1(13: 50-13: 59)$ & 18.8 & 10.1 & 10.1 & 55.3 & NDFB & 4.21 \\
$2(14: 00-14: 09)$ & 190 & 101 & 72.5 & 279 & 11.9 & 82.9 \\
$3(14: 10-14: 19)$ & 95.9 & 25.3 & 17.5 & 242 & 3.5 & 17.9 \\
$4(14: 20-14: 29)$ & 192 & 70.7 & 54.0 & 184 & 75.0 & 135 \\
$5(14: 30-14: 39)$ & 24.7 & NDFB & NDFB & 5.8 & 27.0 & 60.4 \\
$6(14: 40-14: 49)$ & 0.799 & NDFB & NDFB & 1.0 & 1.0 & 2.5
\end{tabular}

\begin{tabular}{|c|c|c|c|c|c|c|c|c|c|c|c|}
\hline \multicolumn{12}{|c|}{ REPARTEE II Dosage divided by total release amount $\left(10^{-7} \mathrm{~s} / \mathrm{m}^{3}\right)$ for source B } \\
\hline \multicolumn{12}{|c|}{ Receptor Position } \\
\hline Exp. No. & 1 & 2 & 3 & 4 & 5 & 6 & 7 & 8 & 9 & 10 & 11 \\
\hline 1 & NDFB & 0.7 & 10.1 & 2.5 & - & 17.4 & 8.3 & 14.4 & 5.8 & NDFB & 5.0 \\
\hline 2 & NDFB & NDFB & 3.2 & 1.4 & 1.6 & 10.6 & 14.6 & 20.9 & 1.5 & 5.1 & 24.1 \\
\hline 3 & - & 6.6 & 12.5 & 4.16 & 3.4 & 15.9 & 4.2 & 4.8 & 15.2 & 0.93 & 54.5 \\
\hline 4 & 2.5 & 14.8 & 24.5 & 10.9 & 6.6 & 12.1 & NDFB & NDFB & 33.7 & 1.7 & 119.2 \\
\hline 5 & 6.3 & 27.1 & 18.7 & 6.8 & 3.0 & 12 & 0.3 & 0.4 & 41.7 & NDFB & 165.3 \\
\hline 6 & NDFB & NDFB & 2.7 & 0.25 & 0.7 & 10.9 & 25.8 & 7.61 & 0.41 & NDFB & 9.8 \\
\hline \multicolumn{12}{|c|}{ REPARTEE II Dosage divided by total release amount $\left(10^{-7} \mathrm{~s} / \mathrm{m}^{3}\right)$ for source C } \\
\hline & \multicolumn{11}{|c|}{ Receptor Position } \\
\hline Exp. No. & 1 & 2 & 3 & 4 & 5 & 6 & 7 & 8 & 9 & 10 & 11 \\
\hline 1 & NDFB & NDFB & 6.9 & 0.6 & - & 13.8 & 1.8 & NDFB & 1.5 & NDFB & NDFB \\
\hline 2 & NDFB & NDFB & 4.1 & NDFB & NDFB & 11.3 & NDFB & NDFB & 0.8 & NDFB & NDFB \\
\hline 3 & - & 1.1 & 6.5 & 0.5 & NDFB & 9.9 & NDFB & NDFB & 5.3 & NDFB & NDFB \\
\hline 4 & NDFB & 1.9 & 12.7 & 1.3 & 0.9 & 6.5 & NDFB & NDFB & 10.7 & NDFB & NDFB \\
\hline 5 & NDFB & 3.7 & 10.9 & 1.5 & 1.4 & 4.9 & NDFB & NDFB & 13.6 & NDFB & NDFB \\
\hline 6 & NDFB & NDFB & 4.6 & 0.8 & NDFB & 11.3 & 1.9 & NDFB & NDFB & NDFB & NDFB \\
\hline
\end{tabular}

between wind speed and height, Equation 2) is greater compared with a plume that fills up more of the boundary layer (Hunt and Weber, 1979).

$U_{Z}=U_{R}\left(\frac{Z}{Z_{R}}\right)^{\alpha}$,

The dependency of $s$ on $\alpha$ has previously been discussed (Calder, 1949; Pasquill and Smith, 1983). Irwin demonstrates that $\alpha$ increases (and therefore also the shape exponent) with increasing surface roughness and atmospheric stability (Irwin, 1979). Only the effect of atmospheric stability (based on the results from the Prairie Grass experiments) had been verified by experimental results before the present study.

It was concluded (Eliot, 1961) that $s<2$ (and closer to 1) for both the Green Glow and the Prairie Grass experiments respectively. Nieuwstadt and van Ulden (1978) concluded (based on the Prairie Grass experiments) that s ranges from 1 in unstable conditions, 1.3 in neutral conditions, and up to 2 in stable conditions. In other words, they concluded that a Gaussian profile is only a suitable description during stable conditions. It should be noted that these values of $s$ were determined for rural areas over relatively flat terrain, but in areas with higher surface roughness, $s$ typically will be higher (as shown later).

The vertical concentration profiles have been compared with the Gaussian plume equation and the results are shown in Fig. 5 for the vertical concentration profiles obtained at three different source-receptor distances used across both campaigns. The results from the experiments, where an obvious elevation above background was seen, have been plotted. Note that the REPARTEE I data is averaged over $9 \mathrm{~min}$ and the REPARTEE II data is effectively averaged over $15 \mathrm{~min}$. Due to the close proximity of source C (see Fig. 1b) to receptor positions, i.e. $460 \mathrm{~m}$, there was limited data for this regime as shown in Table 2.

The profiles corresponding to Briggs urban parameters for Pasquill's stability classes $\mathrm{C}$ and D have also been plotted 

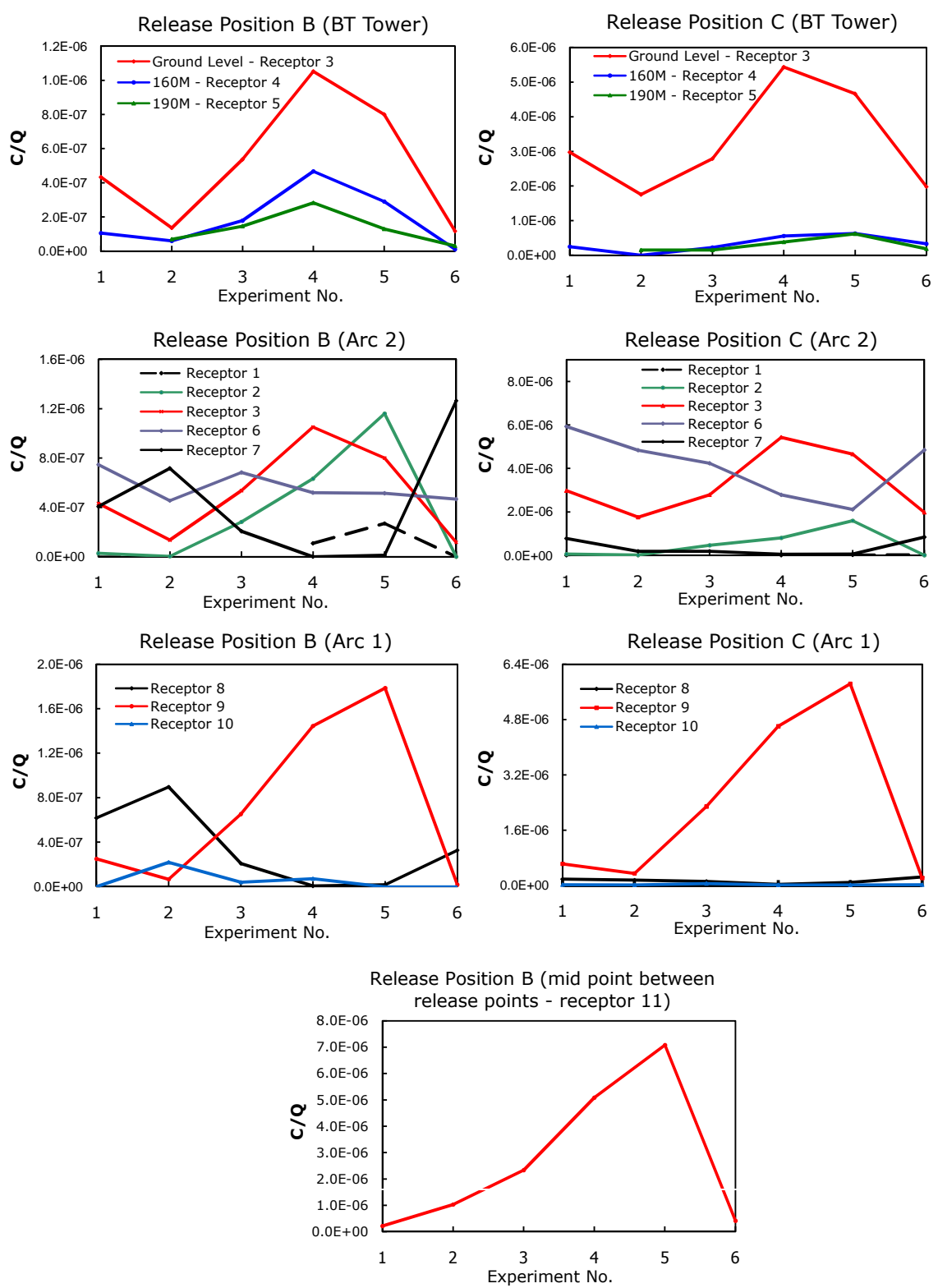

Fig. 4. Time-series of concentration for REPARTEE II.

(Flaherty et al., 2007). From these experiments, it was noted that for the source-receptor distances of approximately 980mthe shape exponent $s$ is close to 2 (Gaussian profile), for distances shorter than $1000 \mathrm{~ms}$ is greater than 2 and for distances longer than $1000 \mathrm{~m}$ less than 2 (a shape in between Gaussian and exponential).

Surface roughness is estimated to be comparable between the 2006 and 2007 campaigns as the wind direction was similar and the urban canopy is reasonably homogeneous. The campaigns were conducted at the same time of the year (26 October 2006 compared with 7 November 2007) and all of the experiments took place during overcast conditions with moderate to strong winds (mean wind speed 12.0 and
$7.4 \mathrm{~m} \mathrm{~s}^{-1}$ respectively for 2006 and 2007. It should be noted that the $\mathrm{s}$ values observed here cannot be used to draw generalized conclusions since the shape of the vertical concentration is also dependent on atmospheric stability and surface roughness; although for source-receptor distances 460 and $980 \mathrm{~m}$ the experiments were simultaneous using different tracers, therefore stability and roughness affect the profiles identically. The results here are closer to Gaussian than have been measured in rural areas during the Prairie gas experiments which may be as a result of the increase in surface roughness. 
Table 3. Meteorological measurements made during REPARTEE I and II. Calculations of wind speed and direction are calculated from a sonic anemometer using double-rotation streamwise analysis (for full details see Wood et al., 2009; Wood et al., 2010).

\begin{tabular}{|c|c|c|c|c|c|c|c|c|c|c|}
\hline \multirow{3}{*}{ Sample No. } & \multicolumn{10}{|c|}{ REPARTEE I Meteorological data } \\
\hline & \multicolumn{6}{|c|}{ BT Tower $(190 \mathrm{~m})^{\mathrm{a}}(51.3117 \mathrm{~N}, 0.1389 \mathrm{~W})$} & \multicolumn{4}{|c|}{ WCC Library $(18.4 \mathrm{~m})(51.5210 \mathrm{~N}, 0.1605 \mathrm{~W})$} \\
\hline & $\begin{array}{l}\text { Wind dir } \\
\left({ }^{\circ}\right)^{b}\end{array}$ & Stdev ${ }^{b}$ & $\begin{array}{l}\text { Wind } \\
\text { speed } \\
\left(\mathrm{ms}^{-1}\right)^{b}\end{array}$ & Stdev ${ }^{b}$ & $\begin{array}{l}\text { Sensible } \\
\text { heat } \\
\text { flux } \\
\left(\mathrm{Wm}^{-2}\right)\end{array}$ & $\begin{array}{l}\text { Local } \\
\text { stability } \\
\text { parameter } \\
\text { (z/L) }\end{array}$ & $\begin{array}{l}\text { Wind } \\
\operatorname{dir}\left(^{\circ}\right)\end{array}$ & Stdev & $\begin{array}{l}\text { Wind } \\
\text { speed } \\
\left(\mathrm{ms}^{-1}\right)\end{array}$ & Stdev \\
\hline 1 & 221 & 3 & 12.4 & 0.6 & 126 & -0.39 & 235 & 31 & 3.9 & 2.5 \\
\hline 2 & 219 & 5 & 10.2 & 1.8 & 20 & -0.12 & 233 & 36 & 3.5 & 2.3 \\
\hline 3 & 218 & 2 & 12.5 & 1.0 & 72 & -0.34 & 243 & 48 & 3.1 & 2.6 \\
\hline 4 & 223 & 2 & 13.0 & 1.2 & 40 & -0.46 & 256 & 40 & 3.2 & 2.4 \\
\hline 5 & 253 & 5 & 10.5 & 1.9 & 24 & -0.16 & 254 & 40 & 3.0 & 2.0 \\
\hline \multirow[t]{2}{*}{6} & 253 & 2 & 14.4 & 1.0 & 36 & -0.38 & 255 & 38 & 2.8 & 1.6 \\
\hline & \multicolumn{10}{|c|}{ REPARTEE II Meteorological data } \\
\hline \multirow[t]{2}{*}{ Exp. No. } & \multicolumn{4}{|c|}{ BT Tower $(190 \mathrm{~m})(51.3117 \mathrm{~N}, 0.1389 \mathrm{~W})$} & & & \multicolumn{4}{|c|}{ WCC Library $(18.4 \mathrm{~m})(51.5210 \mathrm{~N}, 0.1605 \mathrm{~W})$} \\
\hline & $\begin{array}{l}\text { Wind dir } \\
\left(^{\circ}\right)\end{array}$ & Stdev & $\begin{array}{l}\text { Wind } \\
\text { speed } \\
\left(\mathrm{ms}^{-1}\right)^{b}\end{array}$ & Stdev $^{b}$ & $\begin{array}{l}\text { Sensible } \\
\text { heat } \\
\text { flux } \\
\left(\mathrm{Wm}^{-2}\right)\end{array}$ & $\begin{array}{l}\text { Local } \\
\text { stability } \\
\text { parameter } \\
(\mathrm{z} / \mathrm{L})\end{array}$ & $\begin{array}{l}\text { Wind } \\
\operatorname{dir}\left(^{\circ}\right)\end{array}$ & Stdev & $\begin{array}{l}\text { Wind } \\
\text { speed } \\
\left(\mathrm{ms}^{-1}\right)\end{array}$ & Stdev \\
\hline 1 & 280 & 10 & 8.0 & 2.2 & 39 & -0.27 & 272 & 60 & 1.7 & 1.6 \\
\hline 2 & 285 & 9 & 8.9 & 2.3 & 33 & -0.16 & 302 & 61 & 1.6 & 1.6 \\
\hline 3 & 279 & 9 & 8.8 & 2.0 & 38 & -0.16 & 264 & 51 & 1.7 & 1.6 \\
\hline 4 & 272 & 8 & 8.1 & 1.7 & 28 & -0.32 & 260 & 47 & 1.8 & 1.5 \\
\hline 5 & 276 & 9 & 7.3 & 1.5 & 23 & -0.31 & 261 & 47 & 1.4 & 1.2 \\
\hline 6 & 287 & 8 & 7.0 & 1.6 & 13 & -0.29 & 288 & 55 & 1.3 & 1.2 \\
\hline
\end{tabular}

* Wind directions are bearings from North. ${ }^{\mathrm{a}}$ anemometer was clamped to an open lattice scaffolding tower of $12 \mathrm{~m}$ height, situated on top of the main building structure and resulting in a measurement height of $190 \mathrm{~m} .{ }^{b}$ wind direction, wind direction standard deviation, wind speed and wind speed standard deviation obtained from Vaisala WXT510 weather station $1 \mathrm{~Hz}$ weather station.

\subsubsection{Lateral advection and Vertical mixing times}

Given that tracer was detected by the first sample taken at $190 \mathrm{~m}$ (i.e. within the first $9 \mathrm{~min}$ ) this gives a provisional (over-) estimate of the arrival time of $540 \mathrm{~s}$. Previous theoretical studies (e.g. Chatwin, 1968) have been analyzed against data from plumes in the full-scale (e.g. lidar-detected smoke plumes in Mikkelsen et al., 2002) to show that $\sigma_{z} \sim \sigma_{y}=$ $a u_{*} t$ (where $\sigma_{y}$ and $\sigma_{z}$ is the puff size (laterally and vertically respectively), i.e. standard deviation; and $a$ is 0.73 ). For our single point we get $u_{*} t<230 \mathrm{~m}$. Now, at the time of first sample $(9 \mathrm{~min})$ the plume was already of height greater than the BT Tower $(190 \mathrm{~m})$, but for comparison, $\sigma_{z}$ is needed (i.e., less than the height of the plume); hence since the these two factors are acting in opposite directions, and in the interests of parsimony, we must estimate $\sigma_{z}$ as the height of BT Tower $(190 \mathrm{~m})$. Thus for our data $a \geq 0.83$ which is comparable to the Mikkelsen et al. dataset.

The meteorological observations were also used to estimate the timescale for turbulent transport from the surface up to the BT Tower under different stability conditions, the method for which is fully reported in Barlow et al. (2010). A timescale which takes into account the integrated diffusivity can be defined as:

$\tau_{t}(z)=\gamma r_{a}(z) z$

where $z$ is the height up to which material is mixed, $r_{a}$ is the effective aerodynamic resistance and $\gamma$ is a coefficient, initially assumed to be 1 . By comparing the calculated timescale for turbulent transport up to the BT Tower (i.e. $z=190 \mathrm{~m}$ ) with the observed value of $540 \mathrm{~s}$ from the REPARTEE I experiment, it was found that $\gamma \sim 0.2$. The transport timescale $\left(\tau_{t}\right)$ was then calculated for all periods when meteorological data and lidar data were available during the REPARTEE II campaign. The median daytime value for the REPARTEE II campaign was 516s. Overall, using equation 3 with the empirically determined $\gamma$ value gave a near-neutral estimate of $\sim 10 \mathrm{~min}$ for turbulent transport by diffusion up to the BT Tower increasing to $\sim 20$ to $50 \mathrm{~min}$ for the occasional stable conditions observed during the campaign (Barlow et al. 2010).

\subsection{Lateral distribution}

Lateral concentration distributions for all six experiments during the REPARTEE II campaign have been obtained 

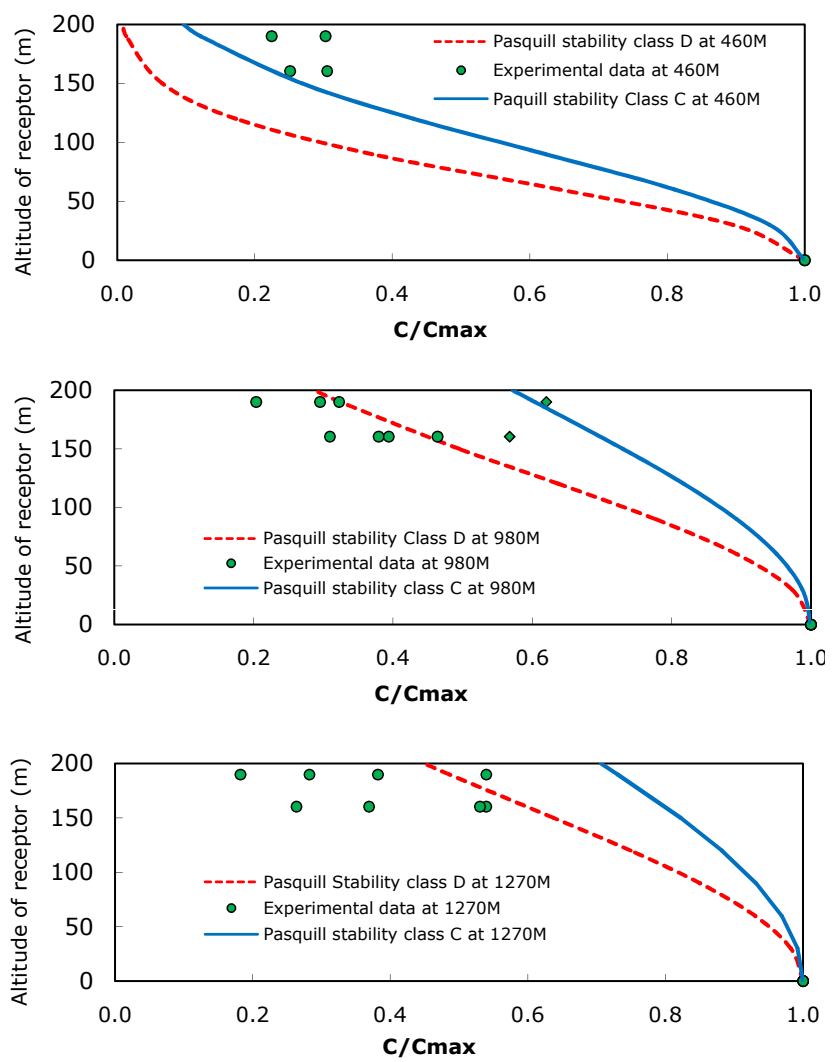

Fig. 5. Vertical gradient profiles for different source-receptor distances: $460 \mathrm{~m}$ (Experiments 4 and 5, 2007 data), $980 \mathrm{~m}$ (Experiments 1-5, 2007 data); $1270 \mathrm{~m}$ (Samples 1-4, 2006 data). Values plotted are those closest to the plume centreline. Vertical profiles are deduced from Pasquill stability classes C and D using Briggs urban parameters.

(integrated 35 min samples). Fig. 6 shows receptor results based on release from position $\mathrm{X}$ for the arc furthest away from the sources, i.e. for receptors 1, 2, 3, 6 and 7. The origin for the lateral distance has been located at the receptor measuring the highest concentration. A positive distance implies going southwards along the arc and a negative distance going northwards. Qualitatively, a Gaussian distribution in the lateral direction seems a reasonable approximation. The width of the plume for an individual experiment is comparable with the width of the Gaussian profile. The asymmetry of the profiles is caused by the limit in the number of receptors, since the receptor measuring the highest concentration is not perfectly on the plume centreline. The approximation of a lateral Gaussian profile (Pasquill stability class D using Briggs urban parameters) was also found to be valid during the BUBBLE experiments with source receptor distances of 700 and $1000 \mathrm{~m}$ (Rotach et al., 2004) as well as in a number of other field experiments (e.g. Davidson et al., 1995 and Andrén 1985).

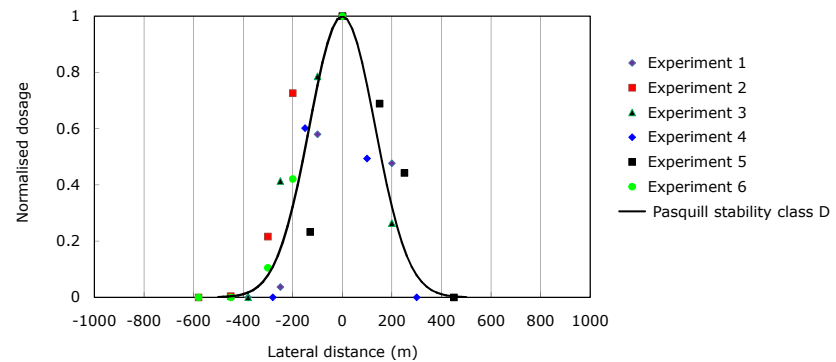

Fig. 6. Lateral concentration profiles during REPARTEE II. Results are displayed based on source $\mathrm{X}$ for the arc furthest away from the sources $(910-980 \mathrm{~m})$, i.e. for receptors $1,2,3,6$ and 7 . The origin for the lateral distance has been located at has been located at the receptor measuring the highest concentration. A positive distance implies going southwards along the arc and a negative distance going northwards. The lateral profile is calculated from Pasquill stability class D using Briggs urban parameters at $950 \mathrm{M}$.

\subsection{Model evaluation}

The dosage, $D$, is defined as the time-integrated concentration, $C$, over an exposure period, $T$ : the exposure period in this case is the sampling period and this has been selected to be sufficient for the whole emitted tracer-cloud to clear the experimental area, in which case $D$ is independent of $T$. The dosage of gas accumulated over the sampling time, $D$ (in $\mathrm{kg} \mathrm{m}^{-3} \mathrm{~s}$ ), is made dimensionless by choosing appropriate velocity scales using the wind speed, $U_{H}$ (in $\mathrm{m} \mathrm{s}^{-1}$ ), since we focus on the neighbourhood scale, we expect the urban geometry to control the dispersion (Wood et al., 2009). It is then appropriate to choose the mean wind speed at mean roof level, $U_{H}$, for a velocity scale and for these data we use the WCC wind speed. Since $U_{H}$ was a useful quantity for analysed DAPPLE data (e.g. Wood et al., 2009), it was also deemed appropriate here since the distances involved are little beyond the near field (as one approaches far field, one might the dilution velocity expect the dilution velocity $U_{d i l}$ where $U_{d i l}\left(=\sigma_{y} \sigma_{z} / U\right)$ to become a more appropriate velocity scale; Venkatram et al., 2004).

This gives the natural dimensionless dosage as:

$D=\frac{D U_{H} H^{2}}{M}$,

where $M$ is total mass of tracer released $(\mathrm{kg})$ and $H$ is the mean building height $(\mathrm{m})$.

These data are then plotted against distance from the source $(x)$ normalised by $H$ where $q$ is the release rate $\left(\mathrm{kg} \mathrm{s}^{-1}\right)$ :

$\frac{D U_{H} H^{2}}{q}=K \frac{H^{2}}{x^{2}}$,

The dimensionless constant $\mathrm{K}$ in the model is likely to depend on urban morphology parameters and is also dependent on which wind speed is being used in the model. Here, 


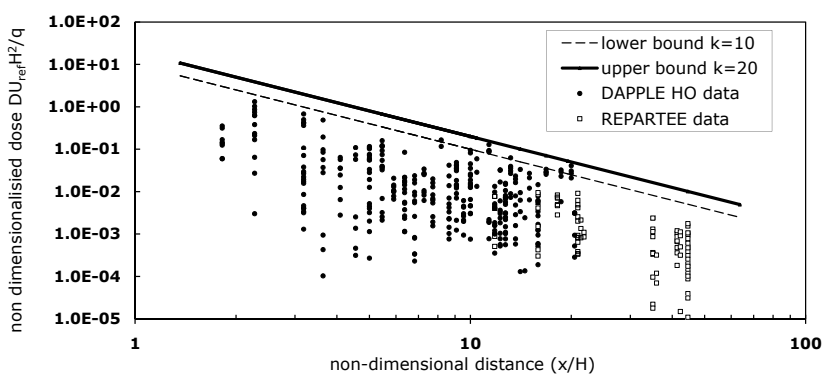

Fig. 7. Evaluation of simple correlation model based on experimental data from both REPARTEE and DAPPLE HO campaigns centred in London.

the chosen wind speed for the BT Tower experiments is the one obtained from measurements on top of Westminster City Council building in central London, UK; where the DAPPLE area is located. Data here are presented in conjunction with tracer data taken from central London measured during the DAPPLE campaign of 2007 campaign for reference (Wood et al., 2009) and allows the study of this relationship over longer distances than had been done previously in the UK and is in reasonable agreement with work carried out in the USA with data pooled from a number of tracer experiments carried out there (Hanna et al., 2007).

The DAPPLE field site is in Westminster, Central London, centred on the intersection of Marylebone Road and Gloucester Place, NW1. These experiments were multiple source dosage experiments from carried out over a number of different wind flow regimes. The correlation is shown in Fig. 7. The simple correlation model does reproduce the upper bound of the concentrations at distances up to $1 \mathrm{~km}$ as found here if an appropriate value of $\mathrm{K}$ is chosen. $\mathrm{A}$ value of $\mathrm{K}$ of 10 encompass almost all cases encountered here whereas a $\mathrm{K}$ of 20 may be used to encompass even the more specific cases when the tracer is channelled in a street canyon. It is worth highlighting at this point that the street network of this part of London is reasonably regular and there are thus long uninterrupted street canyons along which tracer can be channelled (Wood et al., 2009). At longer distances we would expect the effect of street channelling to be minimised, resulting in data falling below the lower bound beyond the near field; and this is indeed the case.

It can be argued that a more sophisticated treatment of data with relation to turbulence characteristics may provide a better bound for the data. Data from the DAPPLE site was studied using a number of screening models including the simple empirical correlation outlined here (Martin et al., $2010 \mathrm{~b})$. The other two models used knowledge of the wind profile, friction velocity, turbulence standard deviations and integral time scales in order to describe dispersion. These other screening models perform well although there are occasions (normally associated with downwind channelling) when they under-predict relevant concentrations. Data was also compared to a street network model (Soulhac et al., 2001). This model represents the effects of local buildings and streets explicitly and is capable of providing detailed prediction of dispersion behaviour at short-to-medium range. The model is based on a street network concept, using street segments and intersections to represent the geometry, with tracer exchanges between streets taking place at the intersections. Performance was generally best for wind directions approximately diagonal to the street axes $\left(\sim 45^{\circ}\right)$, while cases with wind directions almost parallel to the street axis gave results with larger uncertainties (Martin et al., 2010b).

This suggests that channelled downwind flow is the most difficult to describe and that, although simple, the simple empirical used model may be the best description of the data presented here. It is likely that the effect of channelling is reduced in urban tracer experiments in which the average building height is relatively small (e.g. just $4 \mathrm{~m}$ in Venkatram et al., 2004) and where a more parameterized model with regard to turbulence might perform better. Of course, the use of $U_{\text {dil }}(0.1-0.2$ for our rooftop measurements) instead of $U_{H}$ reduces the predicted concentrations: because turbulent motions spread the plume laterally and vertically which slows the forward progression of the plume. However, the use of $U_{d i l}$ is perhaps more appropriate beyond the near field.

\section{Conclusions}

Novel experimental results were obtained from central London dispersion experiments as part of the REPARTEE campaign. Vertical tracer profiles up to $190 \mathrm{~m}$ using the BT Tower were obtained over horizontal distances of up to $1 \mathrm{~km}$ were elucidated using the controlled release of cyclic perfluoroalkanes. Vertical profiles compare reasonably well with the relevant Pasquill stability classes (C and D) using Briggs urban parameters, although it was noted that for source-receptor distances around $1000 \mathrm{~m}$ the shape exponent $s$ is close to 2 (Gaussian profile), for distances shorter than $1000 \mathrm{~m} s$ is greater than 2 and for distances longer than $1000 \mathrm{~m}$ less than 2 (a shape in between Gaussian and exponential).

Plume widths observed during REPARTEE II are well approximated well by a Gaussian profile as was seen in a number of previous dispersion experiments. Estimation of lateral advection time gives similar values to previous studies whilst the calculation of the vertical advection time gives a near neutral estimate of $\sim 10 \mathrm{~min}$ for turbulent transport by diffusion up to the BT Tower.

Experimental data were then pooled with experimental data obtained as part of the DAPPLE campaign (Martin et al., 2010b, Wood et al., 2009). Both these campaigns were based in central London and together looked at distances of $<100 \mathrm{~m}$ up to $1 \mathrm{~km}$. The variation of the non-dimensional dosage is plotted against the 
non-dimensionalised straight-line distance from the source and this illustrates that the empirical upper bound derived from the DAPPLE dataset $(K=10)$ can be extended out to longer range. This decay of downstream concentration is consistent with an inverse square relationship and the extension of the relationship is useful in terms of emergency response planning (Hanna et al., 2007). The street channelling effect observed at shorter distances which resulted in exceeding in a $K=10$ fit was not observed over the longer distances measured here

Acknowledgements. We thank EPSRC, Bristol ChemLabS and the EC through a Marie-Curie Early Stage Training Network (BREATHE) for studentships (IRW, SJH and KFP) and the BOC foundation for funding various aspects of this work. In addition we express gratitude to the DAPPLE consortium for the provision of data as well as for the use of expertise and project resources including time, funds and personnel. Receptor volunteers were Frauke Pascheke, Helen Smethurst, Richard Mohan, Kimberley Bartholomew, Eddy Robertson, Thiuhadini Ngwana, Paul Hayden, Alex Archibald and Roisin Walsh.

Edited by: R. M. Harrison

\section{References}

Andrén, A.: A combined first-order closure/Gaussian dispersion model. Atmos. Environ., 21, 1045-1058, 1987.

Arnold, S. J., ApSimon, H., Barlow, J., Belcher, S., Bell. M., Boddy, J. W., Britter, R., Cheng, R., Clark, R., Colville, R. N., Dimitoulopolou, S., Dobre, A., Greally, B., Kaur, S., Knights, A., Lawton, T, Makepeace, A., Martin, D., Neophytou, M., Neville, S., Niewenhuilsen, M., Nickless, G., Price, C. S., Robins, A., Shallcross, D., Simmonds, P., Smalley, R. J., Tate, J., Tomlin, A. S., Wang, H., and Walsh, P.: Introduction to the DAPPLE Air Pollution Project, Sci. Total Environ., 332, 139-153, 2004.

Barad, M. L. and Fuquay, J. J.: The Green Glow Diffusion Program, Geophys. Res. Papers No. 73, Vols I and II, Geophys Res. Dir., Bedford, Mass., USA, 1961.

Barlow, J. F., Dobre, A., Smalley, R. J., Arnold, S. J., Tomlin, A. S., and Belcher, S. E.: Referencing of street-level flows: results from the DAPPLE 2004 campaign in London UK, Atmos. Environ., 43, 5536-5544, 2009.

Barlow, J. F., Dunbar, T. M., Nemitz, E. G., Wood, C. R., Gallagher, M. W., Davies, F., O'Connor, E., and Harrison, R. M.: Boundary layer dynamics over London, UK, as observed using Doppler lidar, Atmos. Chem. Phys. Discuss., 10, 19901-19938, doi:10.5194/acpd-10-19901-2010, 2010.

Briggs, G. A., Britter, R. E., Hanna, S. R., Havens, J. A., Robins, A. G., and Snyder, W. H.: Dense gas vertical dispersion over rough surfaces: Results of wind tunnel studies, Atmos. Environ., 35, 2265-2284, 2001.

Britter, R. E. and Hanna, S. R.: Flow and dispersion in urban areas, Ann. Rev. Fluid Mech., 35, 469-496, 2003.

Britter, R. E., Di Sabatino, S., Caton, F., Cooke, K. M., Simmonds, P. G., and Nickless, G.: Results from three tracer experiments on the neighbourhood scale in the city of Birmingham UK, Water Air Soil Poll. Focus, 2, 79-90, 2002.
Britter, R. E., Hanna, E. R., Briggs, G. A., and Robins, A.: Shortrange vertical dispersion from a ground level source in a turbulent boundary layer, Atmos. Environ., 37, 3885-3894, 2003.

Calder, K. L.: Eddy diffusion and evaporation in flow over aerodynamically smooth and rough surfaces: a treatment based on laboratory laws of turbulent flow with special reference to conditions in the lower atmosphere, Q. J. Mech. Appl. Math. II, 153-176, 1949.

Chatwin, P. C.: The dispersion of a puff of passive contaminant in the constant stress region, Q. J. Roy. Meteorol. Soc., 94, 350360, 1968.

Cooke, K. M., Di Sabatino, S., Simmonds, P. G., Nickless, G., Britter, R. E., and Caton, F.: Tracers and dispersion of gaseous pollutants in an urban area. Birmingham tracer experiments, Natural Environment Research Council, Technical report, Project Ref: GST/02/1974, 2000.

Davidson M. J., Mylne, K. R., Jones C. D., Phillips J. C., Perkins R. J., Fung J. C. H., and Hunt J. C. R.: Plume dispersion through large groups of obstacles - a field investigation, Atmos. Environ., 29, 3245-3256, 1995.

Draxler, R. R., Dietz, R., Lagomarsin, R. J., and Start, G.: Across North America Tracer experiment (ANATEX): Sampling and analysis, Atmos. Environ., 25A, 2815-2836, 1991.

Elliott, W. P.: The vertical diffusion of gas from a continuous source, Int. J. Air Water Pollut., 4, 33-46, 1961.

Flaherty, J. E., Lamb, B., Allwine, K. J., and Allwine, E.: Vertical tracer concentration profiles measured during the Joint Urban 2003 Dispersion Study, J. Appl. Meteorol. Clim., 46, 2019-2037, 2007.

Hanna, S. R., Britter, R. E., and Franzese, P.: A baseline urban dispersion model evaluated with Salt Lake City and Los Angeles data, Atmos. Environ., 37, 5069-5082, 2003.

Hanna, S., White, J., and Zhou, Y.: Observed winds, turbulence and dispersion in built-up downtown areas of Oklahoma City and Manhattan, Bound.-Lay. Meteorol., 125, 441-468, 2007.

Hunt, J. C. R. and Weber, A. H.: A Lagrangian Statistical Analysis of Diffusion from a Ground-Level Source in a Turbulent Boundary Layer, Q. J. Roy. Meteorol. Soc., 105, 423-443, 1979.

Irwin, J. S.: A theoretical variation of the wind profile power law exponent and a function of surface roughness and stability, Atmos. Environ., 13, 191-194, 1979.

Kim, H., Yea, S. K., Ro, C., Lee, C. B., Jang, M., Lee, G., Yoo, E., and Han, J.: Determination of atmospheric perfluorocarbon back-ground concentrations of fL/L range at the western coastal area of Korea, Bull. Korean Chem. Soc., 23, 301-308, 2002.

Martin, D., Price, C. S., White, I. R., Nickless, G., Dobre, A., and Shallcross, D. E.: A study of pollutant concentration variability in an urban street under low wind speeds, Atmos. Sci. Lett., 9, 147-152, 2008.

Martin, D., Nickless, G., Price, C. S., Britter, R. E., Neophytou, M., Cheng, H., Robins, A., Dobre, A., Belcher, S. E., Barlow, J. F., Barlow, J. F., Tomlin, A. S., Smalley, R. J., Tate, J. E., Colvile, R. N., Arnold, S. J., and Shallcross, D. E.: Urban tracer dispersion experiments in London (DAPPLE) 2003: Field studies and comparisons with empirical prediction, Atmos. Sci. Lett., 2010a.

Martin, D., Price, C. S., White, I. R., Nickless, G., Petersson F. K., Britter, R. E., Robins, A., Belcher, S. E., Barlow, J. F., Neophytou, M., Arnold, S. J., Tomlin, A. S., Smalley, R. J., and Shallcross, D. E.: Urban tracer dispersion experiments during the sec- 
ond DAPPLE field campaign in London 2004, Atmos. Environ., 44, 3043-3052, $2010 b$.

Mikkelsen, T., Jørgensen, H. E., Nielsen, M., and Ott, S.: Similarity Scaling Of Surface-Released Smoke Plumes, Bound.-Lay. Meteorol., 105, 483-505, 2002.

Nieuwstadt, F. T. M. and van Ulden, A. P.: A numerical study on the vertical dispersion of passive contaminants from a continuous source in the atmospheric surface layer, Atmos. Environ., 12, 2119-2124, 1978.

Nieuwstadt, F. T. M. and van Duuren, H.: Dispersion experiments with $\mathrm{SF}_{6}$ from the $213 \mathrm{~m}$ high meteorological mast at Cabauw in the Netherlands, Proceedings of the 4th Symposium on Turbulence, Diffusion and Air Pollution, Reno, Nevada, 15-18 January, 34-40, 1979.

Pasquill, F.: Atmospheric diffusion. The dispersion of windborne materials from industrial and other sources, D. Van Norstand Company Ltd., London, England, 1974.

Pasquill, F. and Smith, F. B.: Atmospheric Diffusion. John Wiley \& Sons, Ltd., New York, USA, 1983.

Petersson F. K., Martin, D., Shallcross, D., White, I. R., Henshaw, S. J., Nickless, G., Longley, I., Percival, C. J., and Gallagher M.: CityFlux Perfluorocarbon Tracer Experiments, Atmos. Chem. Phys., 10, 5991-5997, doi:10.5194/acp-10-5991-2010, 2010.

Robins, A., Castro, I., Hayden, P., Steggel, N., Contini, D., and Heist, D.: A wind tunnel study of dense gas dispersion in a neutral boundary layer over a rough surface, Atmos. Environ., 35, 2243-2252, 2001.

Rotach, M. W., Vogt, R., Bernhofer, C., Batchvarova, E., Christen, A., Clappier, A., Feddersen, B., Gryning, S.-E., Martucci, G., Mayer, H., Mitev, V., Oke, T. R., Parlow, E., Richner, H., Roth, M., Roulet, Y. A., Ruffieux, D., Salmond, J., Schatzmann, M., and Voogt J.: BUBBLE - an Urban Boundary Layer Meteorology Project, Theor. Appl. Climatol., 81, 231-261, 2005.

Shallcross, D. E., Martin, D., Price, C. S., Nickless, G., White, I. R., Petersson, F., Britter, R. E., Neophytou, M. K., Tate, J. E., Tomlin, A. S., Barlow, J. F., and Robins, A.: Short range mobile urban dispersion experiments using an instrumented vehicle, Atmos. Sci. Lett., 10, 59-65, 2009.
Simmonds, P. G., Greally, B. R., Olivier, S., Nickless, G., Cooke, K. M., and Dietz, R. N.: The background atmospheric concentration of cyclic perfluorocarbon tracers determined by negative ion-chemical ionization mass spectrometry, Atmos. Environ., 36 , 2147-2156, 2002.

Soulhac, L., Mejean, P., and Perkins, R. J.: Modelling vehiclegenerated atmospheric pollution in a quarter of Lyon using the model SIRANE. Proceedings of the seventh international conference on harmonisation within atmospheric dispersion modelling for regulatory purposes, Belgirate, Italy, 28-31 May, 2001.

Straume, A. G., Dietz, R. N., N'dri Koffi, E., and Nodop, K.: Perfluorocarbon background concentrations in Europe, Atmos. Environ., 32, 4109-4122, 1998.

Venkatram, A., Isakov V., Pankratz, D., Heumann, J., and Yuan, J.: The analysis of data from an urban dispersion experiment, Atmos. Environ., 38, 3647-3659, 2004.

Watson, T. B., Wilke, R., Dietz, R. N., Heiser, J., and Kalb. P.: The Atmospheric Background of Perfluorocarbon Compounds Used as Tracers, Environ. Sci. Technol., 41, 6909-6913, 2007.

Wood, C. R., Arnold, S. J., Balogun, A. A., Barlow, J. F., Belcher, S. E., Britter, R. E., Cheng, H., Dobre, A., Lingard, J. J. N, Martin, D., Neophytou, M. K., Petersson, F. K., Robins, A. G., Shallcross, D. E., Smalley, R. J., Tate, J. E., Tomlin, A. S., and White, I. R.: Dispersion experiments in central London: the 2007 DAPPLE project, B. Am. Meteorol. Soc., 90, 955-969, 2009.

Wood, C. R., Lacser, A., Barlow, J. F., Padhra, A., Belcher, S. E., Nemitz, E., Helfter, C., Famulari, D., and Grimmond, C. S. B.: Turbulent flow at 190 metres above London during 2006-2008: a climatology and the applicability of similarity theory, Bound.Lay. Meteorol., 137, 77-96, 2010. 